\title{
WHAKAPAPA IN ANTHROPOLOGICAL RESEARCH ON TUBERCULOSIS IN THE PACIFIC
}

\author{
Julie Park, Judith Littleton, Anne Chambers \& Keith Chambers
}

\begin{abstract}
As a theory of knowledge encompassing ecological and cosmological frameworks, Maori whakapapa of non-human species bring a diverse array of emergent entities into kinship relations over time and space. Whakapapa narratives explain the coming into being of those relationships and their moral foundations in utu (reciprocity). In this paper, the authors demonstrate that the 'mind map' (Roberts, 2010) of whakapapa can provide a coordinating framework for social theories of complexity used in medical anthropology. In the New Zealand context in particular, a whakapapa approach also responds effectively to the challenge posed by Gillett (2009:98): 'How exactly should we position indigenous knowledges in a discussion of policy in post-colonial society?' We conclude that the principle of utu provides both a workable local social theory and a moral framework that can be used to assess policies which shape peoples' lives, in this case, the lives of New Zealand-connected Tuvaluans who are contending with tuberculosis in our shared transnational space.
\end{abstract}

One of the conceptual problems we face in our current research project, 'Transnational Pacific Health through the Lens of Tuberculosis,' ${ }^{1}$ is understanding and theorising multiple, interconnected, lineal and lateral linkages which are part of contemporary patterns of tuberculosis (TB), both in New Zealand and in the wider Pacific region. The theme for the 2010 ASAANZ conference 'Ancestry, genealogy, whakapapa' provoked us to think about these interlinkages using a concept of whakapapa (genealogy) as a theoretical frame to analyse the complex transnational ecological linkages surrounding contemporary TB in the Pacific. In doing so, we reflected on whakapapa both as social theory and as a foundation for policy critique. 
Although the case study we explore concerns transnational Tuvaluan health, our analysis is not of Tuvaluan society and culture per se but of the health effects of colonial and post-colonial social, political and economic relations involving most especially, Great Britain, Tuvalu and New Zealand. We particularly wish to use whakapapa as social theory. Our goal is to respond to Gillett's (2009) challenge: 'How exactly should we position indigenous knowledges in a discussion of policy in post-colonial society?' and to draw explicit connections with New Zealand immigration policy.

This concept of whakapapa is drawn specifically from the work of Mere Roberts and her co-researchers as detailed in 'Whakapapa as a Maori mental construct' (Roberts, Haami, Benton, Satterfield, Finucane, Henare \& Henare, 2004), which used whakapapa of kumara, (sweet potato) as a case study. Of particular interest to us was the contrast between this whakapapa and that of humans: that of the kumara contained multiple plant and animal species as well as non-biological entities; whereas, that of humans is confined to a single species. It is particularly the whakapapa of relationships among non-humans that provide our analytic frame. In this work and subsequent papers, Roberts (2010, in press), suggests that a concept of kinship provides the underlying rationale for the relationships between these entities. The principles which Roberts (in press) identifies include those of ontology or creative relationships linking the coming-in-to-being of the cosmos, ancestral beings, and the cultural organisation of the earthly realm, as well as taxonomy or the processes of ordering and classifying, and spacio-temporal understandings of ecosystem relationships. For example, the kumara whakapapa contains a range of climbing plants and other root crops, kiore (the Polynesian rat), caterpillars, and the star, Vega, as well as the gods. Whakapapa, therefore, act as mind maps. In addition, whakapapa and their associated narratives provide moral direction and instruction; for example, about tuakana-teina (senior-junior) relationships, utu (reciprocity, repayment, retribution) and other foundational principles of Maori life. In our discussion we concentrate on the function of whakapapa as a mind-map and its implicit moral connection, specifically the principle of utu.

Through its lateral relations among nonhuman species, as well as the more common understanding of it as ancestry or genealogy, whakapapa can literally mean 'placing in layers' a range of relationships over time. Whakapapa uses what we might call an ecosystem approach, classifying together entities which are related in a variety of ways, not all of them simply biological. Explanations for these relationships can be found in narratives associated with specific whakapapa where multiple levels of knowledge, including moral knowledge, are embedded. Misdeeds such as theft and spying receive punishment; correct 
actions, such as observing tapu, bring social rewards. Risk-taking is sometimes punished, but may also be rewarded under appropriate circumstances. The principle of utu is at work in these narratives.

Utu has had a long history in anthropological theory, being used by Mauss (1969 [1950]:9) to refer to the eventual 'repayment' of a gift. Margaret Kawharu has recently revisited this concept in a study of the Treaty claims process. She noted that it is frequently misunderstood as revenge but that scholars such as Firth and Metge see it as a general principle of reciprocity, both positive and negative, and as a fundamental principle of Maori social relations, as relevant to the present as it is to the past (Kawharu, 2010:29). These reciprocal social relationships, positive and negative, are embedded in whakapapa narratives.

Roberts et al. (2004) apply the results of their study of whakapapa to a discussion of issues relating to genetic modification, seeking both practical and moral guidance, particularly in relation to emerging biotechnologies in the New Zealand context. They broaden the discussion and leave it open-ended but with some tentative guidelines established. In our paper, we adopt this model of whakapapa as a mind map of a cosmological/environmental realm to explore a specific outbreak of tuberculosis. We use their explication that the layered relationships in non-human whakapapa are not usually confined to single species (as defined by current cosmopolitan science), are temporal and spatial and not necessarily genealogical, and may depend on resemblances as well as being specific to eco-systems and place, as in the case of kumara (Roberts et al., 2004:20). ${ }^{2}$

In using whakapapa as a social theory to analyse historical and contemporary interconnections pertaining to a specific outbreak of TB, we are responding, in part, to post-colonial critiques that anthropologists reduce what might be construed as indigenous social theory to data, rather than recognising it as theory (e.g. Hountondji, 2002). We are also suggesting, as does Hountondji, that it is not necessary to see indigenous and non-indigenous theories as necessarily opposed. Following the logic of Mila-Schaaf's (2009) discussion of the creation of a negotiated space for the development of hybrid (our term) ethical theory and practice in Pacific research, which refuses two oppositional systems, we suggest that there is a space for such negotiations about analytical theory too. Gillett (2009:111) takes this idea further, urging scientists to put indigenous knowledges to work rather than just treating them with 'exquisite politeness. This is exactly our goal in this paper.

Bamford (2007) provides an exemplary model for our work. Using world views 
with which she had become familiar through detailed ethnography with the Kamea of Papua New Guinea, Bamford developed novel insights regarding current social issues relating to the use of biotechnologies in Euro-America societies. Her analysis produced a new awareness of taken-for-granted, naturalising assumptions in Euro-American social and bioethical thought, opening these up for further discussion and broader policy considerations. She thus engaged in a fundamental goal of anthropology: cultural critique, by making the familiar strange.

Several other examples using theoretical concepts drawn from Polynesian culture also exist (Huffer \& Qalo, 2004) but their aim is rather different: to use local social theory to analyse local phenomena in order to more accurately capture the nuances of those phenomena, as well as to provide a culturally-appropriate guide to action, whether it involves research, peacemaking or social work. Although none of the scholars in question would necessarily point to Strathern's discussion of 'anthropology at home' as their inspiration, they would likely agree with her assertion that 'whether anthropologists are at home qua anthropologists ... is decided by the relationship between their techniques of organizing knowledge and how people organize knowledge about themselves' (Strathern, 1987:31). Recent examples of the theoretical use of local concepts are the application by Lilomaiava-Doktor (2009) of the Samoan concept of malaga (movement) to understand transnationalism, the development of talanoa (story telling) as a model of (and for) knowledge production (Vaioleti, 2006), and the concept of te'u le vā (Samoan) / tauhi vaha'a (Tongan) (care for the relationship) (Thaman, 2004; Anae, Mila-Schaaf, Coxon, Mara \& Sanga, 2010) as a framework for creating ethical relationships in research and other pursuits. Common to these examples is the axiom that relationships, together with the culturally specific values and practices that create and maintain them, should be fundamental to all scholarly endeavour.

Our use of whakapapa draws on these disparate traditions: using a lens of 'strangeness' to enhance familiar analyses, using local social theory analytically, and pressing it into service to reflect critically on policy. Although the reach of our project is transnational, our team is based in (aspirationally) bicultural New Zealand with two members from the United States. The policy that we critique is New Zealand's policy relating to immigration. The 'people' in question here are Polynesian peoples, specifically Tuvaluans, who are themselves mobile and who have engaged in a range of transnational practices for centuries. While whakapapa is a Maori concept, it has moved into New Zealand English $^{3}$ and has cognates or parallels in other Polynesian languages. In Cook Islands Maori, it is 'akapapa'anga. Samoan uses the term gafa (also used in Tu- 
valu), whose meanings also include fathom - the measure of length equivalent to the human width with both arms outstretched - and line. In Tuvaluan, the closest parallel noun is telega. Its range of meanings includes the act of running as well as the act of smoothing timber through the use of a plane. The cognate verb fakatele can mean 'tell /recite (run out) your genealogy'. The word fakapaapaa is used in Tuvaluan but refers to the process of flattening, such as smoothing out cloth or a mat which has been rolled up, rather than to ancestry. ${ }^{4}$

The researchers in this project come from a range of countries and include Cook Island and Tuvaluan scholars. We live, work in, and are committed to this 'sea of islands' (Hau'ofa, 1993), including the hope of enabling better understandings about New Zealand's place in it. Whakapapa can thus be seen as a familiar way of thinking about people, their mobilities, and the va (spaces between) as these relate to historical and contemporary patterns of health and disease. But at the same time, it offers the possibility of developing fresh, locally-salient understandings about the TB outbreak in Auckland by using a perspective additional to that provided by general social science and health frameworks. In this sense, it also has the potential to provide a helpful critique.

We begin with the environmental realm indicated by whakapapa as a way of understanding the complex historical and transnational linkages that have led to the current pattern of tuberculosis, the subject of this case study. This is the theoretical framework from which whakapapa narratives can emerge/ be constructed. Secondly, we assess whether the theory of whakapapa confers any analytical advantages compared with other models. The interlinkages with which we are concerned can be conceptualised as being within and between species (human and bacteria among others), and as linking social conditions (including colonial and post-colonial power relations), socially responsive physical environments (climate change, crowding, geology), and mobilities of people, things and ideas in transnational fields. Our project has used a range of theoretical concepts to help us address these complexities, including syndemics (Singer \& Clair, 2003), transnational social fields (Schiller, 2007), and historical political ecology (Baer, 2009). Each provides useful vantage points, but is inevitably partial. Our paper concludes with a demonstration of the additional benefit that whakapapa can contribute to policy analysis.

\section{A TB OUTBREAK IN AUCKLAND IS THE FOCUS}

The environmental realm with which we are concerned in this paper is that of tuberculosis as it occurs in the small Tuvaluan community in Auckland, as well 
as in Tuvalu. The outbreak of TB that we take as our focus was documented within the Tuvaluan community in Auckland in 2002 and 2003. Analysis of the part of the outbreak affecting children was published by members of Auckland Regional Public Health Service (Voss, Campbell, Tildesley, Hay, Vaughan \& Thornley, 2006). Our research project seeks to understand this outbreak as part of the broader picture of Pacific tuberculosis including Tuvalu, New Zealand and the Cook Islands. In this outbreak, 24 children and young people developed TB disease, along with a number of adults (the details of the adult part of the outbreak are not yet published). Five more children became infected with TB, that is, TB in its latent form. A few of the children had lasting effects from their illness. The large number of children affected in the small Auckland Tuvaluan population ${ }^{5}$ was distressing to health workers and the families. TB in children is an especially worrying disease; treatment involves months of taking rather unpleasant medication, and Tuvaluan families with TB may suffer from stigmatising behaviour as well as long memories of what TB used to be like before there was effective treatment (Resture, Park \& Littleton, 2009).

The whakapapa notion of a kinship-based environmental realm can help us understand why this disease was so extraordinarily successful in the 'first world' setting of Auckland City in the early 21st century. In accordance with the moral thrust of whakapapa narratives, we also draw out implications for action. We are not suggesting that any extant whakapapa or associated narrative actually depicts humans, TB bacteria, and other actors as having relationships with each other or with this Auckland TB outbreak. Rather, we are creating this narrative by tracing relationships among seemingly disparate entities which have a documented bearing on this environmental realm of TB. But first, a modest amount of information on that complex disease, tuberculosis, is necessary.

\section{INTRODUCING TB}

Mycobacterium tuberculosis is a bacterium that has been associated with humans and some other animals in many parts of the world for several millennia. It passes from one person to another through aerosolised droplets. When these are inhaled three things can happen: a person may not become infected, or may be infected but not develop disease (latent TB), or may develop TB disease (active TB). People who are infected may also develop TB disease much later if their immune system is compromised in any way, such as through having another disease or experiencing significant stress (Littleton and Park, 2009). TB can affect a number of sites in the body but only TB in the lungs is infectious. A TB outbreak occurs when TB disease passes between two or more persons. 
The DNA of TB bacteria can be analysed to see how close the genetic relationship is between different TB samples, producing a genetic genealogy. Thus, it is now possible to identify clusters of infection in New Zealand. Identifying a cluster depends on positive identification of the same strain of TB in all those infected, which differs from other TB strains in the community. Analysis of clusters using DNA allows the probable path of infection to be traced over time, and for those infected with TB whose strain is different to be excluded (Sexton, Perera \& Pandey, 2008). While the date of diagnosis assists with determining the direction of infection, it is only a rough guide, as there may be diagnostic delay and the first case identified may not be the source case. Young children are unable to transmit disease, mainly because they have less productive coughs, so age also provides clues about direction and time of transmission. Typically, adults infect children, as occurred in the outbreak which is the focus of this analysis (Voss et al., 2006).

\section{THE OUTBREAK}

The Auckland Tuvalu outbreak in 2002-3 involved ten Tuvaluan households; the disease did not spread beyond the Tuvaluan community. Large interconnected families were caught up in it. They were linked in several ways and particularly though a woman (the initial source), the mother of the child first diagnosed, who herself had undiagnosed active pulmonary TB disease for several months and had stayed in several different households, providing informal help with childcare (Voss et al., 2006). The Auckland Regional Public Health Service worked extremely hard to limit the spread of TB and to treat all involved but they were hampered by inter-household movement, difficulties in tracing people, and unfamiliarity with this 'new' Pacific community. In a few cases, people were reluctant to declare themselves to authorities, perhaps because of their immigration status or the stigma surrounding TB (or all of the above) (Voss et al., 2006). Ng Shiu (2008) and Hay (2009) who, in conjunction with our project, carried out research in Auckland with Pacific people, including Tuvaluans, found that all these factors were important contributors to diagnostic delay and difficulties in contact tracing.

In case finding, public health nurses and community workers ask about the possible contacts of those who have been infected. They then test the contacts, and after a positive diagnosis is made, administer medications as necessary (Miller, 2007). Many of the persons with active disease or infection were discovered in this way. But others with TB disease were linked into the cluster not through active case finding, but because they attended health services independently for a range of symptoms and were found to have TB of the same 
strain. In other words, they were linked to the outbreak in the lab, not the field (Voss et al, 2006). It is quite common in DNA studies for social networks to be discovered only through DNA analysis of the TB bacteria, as people have a range of reasons for not disclosing social contact, in addition to simply forgetting. Clusters can persist over a period of months or years, and DNA analysis is the only effective way to determine whether the cases are related.

In this outbreak, the woman who was the source of infection had been in New Zealand for about a year. The difficult circumstances in which she found herself in New Zealand may have activated a latent infection. On the other hand, it is possible that she had the disease when she came to NZ. In Tuvalu, as in most Pacific Island countries, DNA analysis of TB bacteria is not possible and while testing for the presence of TB disease is currently carried out, even basic testing was difficult in the past (Resture, 2010). Thus, while it is not possible to say definitively that this outbreak involved a strain of TB from Tuvalu, it is very likely that another part of the cluster was located in Tuvalu. Given the transnational lives of Tuvaluans, related parts of the outbreak may have occurred in other places as well.

Around this time, between 1999 and 2003 especially, medical services in Tuvalu were struggling to create an effective detection and treatment programme for TB. The successful treatment rate had dropped below 40 per cent in 2002 and the incidence rate of TB disease that year was around 200 per 100,000. The situation has since improved. Latest figures (for 2009) indicate a much higher success rate in treating the approximately 18 new cases a year, and the estimated incidence has declined to about 155 per 100,000 (WHO, 2011a; WHO, 2011b). In 2007, Tuvalu had the third highest TB case notification rate in the 19 Pacific Island countries and territories (excluding PNG) surveyed by Viney, O'Connor \& Wiegandt, (2011). ${ }^{6}$ While TB rates fell sharply after the 1950 s for New Zealand Maori (Dunsford, 2008), and after the 1960 os for Cook Islanders (Futter-Puati, 2010) in response to strenuous efforts to reduce the burden of disease, in Tuvalu they have declined only in the last twenty years - between 1990 and 2009 the incidence of TB in Tuvalu approximately halved (wHO, $2011 \mathrm{a} \& \mathrm{~b})^{7}$

It is highly likely that there was no TB in Tuvalu, or elsewhere in Western Polynesia, before colonisation by Europeans (Miles, 1997: 69). Thus, to understand how the current situation has come about, earlier layers of this whakapapa must be uncovered. This exploration broadens the geographic scope of our inquiry and introduces several new participants into the 'mind map'. 
Tuvalu was formerly known as the Ellice Islands and was administered as a British protectorate and colony jointly with the Gilbert Islands (GEIC) from 1892. It formed part of the Western Pacific High Commission (WPHC) which had been created in 1887 (Macdonald, 2001). Tuvalu's engagement in globalisation through missionisation, colonisation and especially labour circulation, was the likely source of TB introduction, probably in the 19th century when TB was very prevalent in the colonising nations. Though there had been occasional sporadic European contact attempts with various islands from as early as 1568 , as well as whalers' visits in the early nineteenth century, occasional foreign sojourners, and some engagement of local people on foreign ships, it was not until the second half of the nineteenth century that sustained contact with the European world was established (Macdonald, 2001). This was mainly through resident Samoan pastors from the London Missionary Society initially, backed up by periodic visits from the mission ship with its European goods and European missionaries. A small number of other foreigners settled and founded families, increasing exposure to European ways (Chambers \& Chambers, 2001).

Much of the funding of the colony came from the phosphate mining industry developed on Ocean Island (Banaba), which was in the hands of a partnership formed in 1920 between Britain, Australia and New Zealand, known as the British Phosphate Commission (в РС) (Foreign and Commonwealth Office, 1971). Ellice Islanders worked in the mining operations and as boatmen on both Ocean Island and Nauru, as well as further afield, such as in coral mining operations on Johnston Island. Ocean Island had been claimed by the British in 1900, following discovery earlier that year of its huge deposits of high quality phosphate (Williams \& Macdonald, 1985). On these heavily mined islands, people from many different countries in Europe, Asia, the Americas and the Pacific mingled at close quarters, and TB was known to be a serious scourge.

For Ellice Islanders after the Second World War, TB certainly posed a serious health problem, regardless of whether they remained at home or worked on Ocean Island. This is made abundantly clear in the colonial administration's assessment of the 1945 Ellice Islands Annual Report, which had been commended as 'reasonably accurate and comprehensive' even though its author, District Officer R.G. Roberts, had assumed his post only ten days earlier. When the report was forwarded on to the Western Pacific High Commission a few months later, however, Acting Resident Commissioner Wernham felt obliged to append a cautionary clarification. He wrote: 
It is necessary, however, to comment on p. 6 of the report, in which it is stated that 'apart from some scattered cases of elephantiasis, yaws and filariasis, the health of the people appears very satisfactory. In fact, no statement regarding the health of the Ellice Islanders is complete without a reference to the high incidence of tuberculosis. With regard to filariasis, I have always understood that tests performed by the в РС on Ellice Islands labourers on Ocean Island have indicated that over $75 \%$ of the population of the Ellice Islands suffer from filariasis.... At present it would be a mistake to regard the health of the Ellice Islands as a matter for satisfaction. ${ }^{8}$

Since filariasis (a mosquito-borne helminth or parasitic 'worm') is known to increase susceptibility to TB (Elias, Britton, Kassu \& Akuffo, 2007), the Ellice labourers' high rate of infection from filariasis as well as other helminths such as hookworm (Miles, 1997:75) probably had created a syndemic situation between the two diseases, with other common illnesses and yaws worsening the situation further. The post-contact introduction of tobacco into the Pacific created a further negative element in these syndemic relationships. Tobacco smoking has multiple interactions with tuberculosis (Littleton \& Park, 2009) and tobacco was widely used by contracted employees.

Since labourers on Ocean Island were typically hired on short-term contracts, the result was a continual flow of potential infection and re-infection around the GEIC. Though the colonial administration seems to have understood the health risk in this situation enough to design a screening system intended to prevent active cases from returning to their home islands untreated, circumstances could sabotage preventative intentions. For example, in Appendix II on Ocean Island in the 1946 'Medical and Sanitary Report' for the Colony, Rose, the Senior Medical Officer for the GEIC, notes that on Ocean Island: 'Clinically, there were a number of labourers with pulmonary tuberculosis. The late arrival of X-ray film has prevented the confirmation of the clinical diagnosis before the labourers were repatriated.' ${ }^{9}$ In other words, people presumed to have active TB were not treated before they were repatriated, mingled with uninfected co-workers on the ship home, and then re-entered their home island communities where they could spread TB to even more people. In the same Appendix, Rose also noted that a large outbreak of influenza followed the arrival on Ocean Island of 'Chinese mechanics' and that many people living on the island had developed pneumonia as a result. Rose stated his intention of procuring (unspecified) vaccine before the next lot of recruits arrived. Elsewhere in this report Rose described an outbreak of measles which particularly affected three Tuvaluan islands and caused deaths there. In this case, returning 
workers from Johnston Island were the likely source.

Colony and District annual reports provide nearly-continual references to ship-introduced disease outbreaks over the years, including incidents of dysentery in 1947 and polio in 1952 (see Resture, 2010 for further examples; Chambers and Chambers, 2001:77). ${ }^{10}$ Effective treatment of such outbreaks was almost impossible because they usually developed after ships had departed and swept rapidly through communities that lacked both previously-developed resistance and adequate medical supplies. Official reports suggest that living conditions and health services on the phosphate islands were better than in other Pacific islands. However, it seems more likely that this assessment mainly took account of the existence of some specific health services (for example, the filariasis testing mentioned earlier and better hospitals). Actual living conditions were far from ideal and factors such as phosphate dust, drought, periodic food shortages, a limited diet, and, at times, crowded residences and mingling of people from many islands and countries facilitated the spread of diseases, making health services even more crucial.

It seems likely, in fact, that poor living conditions would have offset any benefits from health services, as well as significantly adding to the general burden of disease which circulated within islands and between neighbouring islands. Teaiwa (2005), writing about Banaba/Ocean Island, notes that the presence of Banabans, Europeans, Gilbert and Ellice Islanders, and workers from Japan and Hong Kong is documented in 80 years of images, including silent film. While islander communities were normally separated into different work and residential groupings, many aspects of their lives also intersected, as described by colonial officer Arthur Grimble (1952), facilitating the circulation of diseases such as influenza, polio, measles, TB, and dysentery.

The phosphate produced on Ocean Island was essential to the agricultural economies of New Zealand and Australia (Williams, 1971; Williams \& Macdonald, 1985). It was also transported elsewhere, earning valuable income for the в РС and the Colony, as well as for the labourers involved (Teaiwa, 2005:180). Yet Britain's Pacific colonies were regarded as uneconomic, the poor 'Cinderellas of the Empire' (Grimble, 1957:5; Macdonald, 2001). In this 'backwater', resources were perennially short. Expenditures on health services competed with those for colonial administration, and typically lost out.

As late as 1971, colonial officers about to take up a position in the Gilbert and Ellice Islands (shortly to become Kiribati and Tuvalu) were warned in a booklet about island life that 'Tuberculosis remains the most important major 
public health problem in the Colony' (Foreign and Commonwealth Office, 1971:17). Clearly, this fact was a point of active administrative concern. The South Pacific Community (SPC), the South Pacific Health Service, Colony doctors and health assistants tried many times to mount comprehensive anti-TB campaigns for several decades in the post-WwII era once effective diagnostic and treatment methods had been developed. But there always seemed to be pieces of the puzzle missing. For example, the ship Kiakia which had been purchased in 1938 for health-related transport was never in fact allocated to this purpose, even after the war (Resture, 2010:31). Similarly, purchase of a mobile health unit immediately after the war was deferred for financial reasons and was eventually acquired in 1950 with money from the South Pacific Board of Health, not the Colony's budget (Resture, 2010:36). For a diagnostic and treatment effort to succeed, money, technology, expertise, pharmaceuticals, $\mathrm{X}$-ray and testing equipment, labs for culturing specimens, health personnel, refrigeration and shipping all needed to be lined up at one time. On the few occasions when campaigns did go ahead, Tuvaluans welcomed them and local communities willingly provided support to the workers combating this disease that they feared (Resture, 2010).

When Tuvalu separated from the Gilbert Islands and became an independent member of the Commonwealth in the 1970s, it inherited an inadequate health system, signalled by continuing high rates of what had become an eminently treatable disease: TB. As a result, the current health services of independent Tuvalu must still cope with health challenges that are the product of decades of neglect, a preeminent example of which is the high, only recently-reducing, incidence of TB. Treatment and prevention efforts focused on TB use precious health resources, especially when the length of time it takes to successfully treat each TB case (a minimum of six months), the contact tracing involved, and the monitoring of people with infection, are considered.

Emerging from this history is a colonial narrative which helps to explain how TB emerged and flourished in Tuvalu. Commencing with TB's introduction by foreigners (sailors, whalers, missionaries, officials) to local families, TB was then spread to kinsfolk and others through the ordinary movement of people within and between the islands. Local people were well aware that the advent of new illnesses was an inevitable by-product of external contact. TB's spread was further enhanced by labour migration related to the Colony's lucrative extractive industry, phosphate mining. People from many different countries, some of which had very high TB rates (Lei, 2010; Johnston, 1995), met and interacted at close quarters on the phosphate islands. ${ }^{11}$ TB's success was also likely increased by high levels of helminth infections, and by the living and 
working conditions, endured by phosphate workers and their families (Teaiwa, 2005).

The phosphate industry made money for the B $\mathrm{CC}$ and provided a key agricultural input for the farms of Australia, New Zealand and other countries. These farms in turn were meeting Britain's need for food: another colonial branch of this whakapapa. Extremely tight purse strings on the colonial administration, inability to earmark and protect resources for health, rapid turnover of personnel, and the myriad practical difficulties of getting TB campaigns organised, meant that extremely high TB rates prevailed until the last decades of the 2oth century, well after effective treatments were available. While Tuvaluan rates have fallen in response to concerted efforts by health workers during the last two decades, they are still relatively high by wHo standards (Gani, 2009; Viney et al., 2011). In addition to those with diagnosed TB, many people currently living in Tuvalu or moving within its transnational space will have been exposed to TB over their lifetimes and some of these will have latent infection.

THE TUVALUAN ECOSYSTEM

About half the nation's 10,500 people currently reside on Funafuti, Tuvalu's capital island and administrative centre. Residents must cope with serious housing problems, few sources of employment other than government jobs, problems with food quality and supply, and periodic shortages of water (wHO, $2011 \mathrm{a} \& \mathrm{~b}$ ). In this socio-biological ecosystem, mutually interactive noxious conditions combine with a range of communicable and non-communicable diseases to create a TB syndemic that requires much effort to mitigate. The other eight islands do not suffer from comparable crowding, but their residents also endure food and water shortages from time to time. Distance from health facilities in the capital can inhibit timely treatment of TB (and other diseases) for outer islanders, and causes considerable inconvenience and expense since patients must travel to Funafuti by boat for treatment and shipping services are infrequent. In addition, obesity and diabetes is also extremely prevalent among Tuvaluans, both those in Tuvalu and in New Zealand (Gani, 2009). Diabetes interacts negatively with TB. People with diabetes are more likely to progress from TB infection to TB disease and treatment of both conditions is difficult (Littleton \& Park, 2009; Curry International Tuberculosis Center, 2010). Diabetes too has a complex whakapapa in which colonisation and food and water insecurity are also implicated; it appears these two whakapapa are in the process of becoming conjoined. Present day conditions in Tuvalu, themselves the result of geopolitical relations past and present, are thus also part of a complex causal layering that must be explicated. 
But Tuvalu has agency and assets as well as problems. Although measuring only 26 kilometres square in terms of land (the fourth smallest nation), it has a seat in the United Nations and has rights to a large area of ocean (and fisheries) via its exclusive economic zone of 200 nautical miles around the $676 \mathrm{k}$ long island chain. These assets result in interest from several donor countries, and the EU. However, balancing the budget and safely managing the Trust Fund of this resource-poor country is a continuing problem (CIA, 2011), as is maintaining a stable government.

New Zealand, as noted above, was involved in the phosphate trade, made a substantial initial grant to the Trust Fund in 1987 and continues as an important donor. Unlike other Polynesian groups such as the Cook Islands or Tokelau, Tuvalu did not have a close political relationship with New Zealand in colonial times. ${ }^{12}$ As a result, while Cook Islanders and Tokelauans are New Zealand citizens by birth right, Tuvaluans are not.

Tuvalu is thoroughly enmeshed in global and regional systems through economics and aid, new labour migrations (including that of mariners trained in Tuvalu) and remittances, international religious organisations, education networks and so on. The travels of its people via air and boat, and their use of electronic media including internet, DVDs and TV, continue to increase (Chambers \& Chambers, 2001). People have emigrated and returned for many decades, as indeed they also did to a lesser extent in pre-colonial times. But now they can go much further. Tuvalu has already felt some effects from global climate change, being only $4.5 \mathrm{~m}$ above sea level at its highest point. Fears of increasing salination of gardens, the possibility of erosion, bigger storm surges and more unpredictable weather conditions, have motivated some families (but by no means all) to seek to migrate more permanently. This is not just for traditional reasons of education, employment, health and bright lights, but because people are increasingly uncertain about the future in and of Tuvalu, for themselves and especially for their children. However, would-be migrants must overcome many barriers before they are accepted as immigrants, including strict immigration controls by their more economically advantaged neighbours of Australia and New Zealand. Global flows of people and resources have their limits. They are structured by, and must conform to, the dictates of economic and political power relationships.

TUVALUANS IN NEW ZEALAND

As a consequence, Tuvaluans are relatively recent arrivals in New Zealand and even now number just a few thousand. Since 2002, the Pacific Access Category 
has allowed up to 75 Tuvaluans and their immediate families to immigrate to $\mathrm{NZ}$ each year provided they meet strict conditions. ${ }^{13}$ In addition, small groups of Tuvaluans are brought to NZ on seasonal employment schemes for up to nine months at a time (Bedford, Bedford \& Ho, 2010). These schemes are now very carefully monitored in an attempt to ensure everyone returns home, especially since oversight was more lax in the 1990 os and some Tuvaluans stayed on. Others have overstayed on visitors' visas. People with an undocumented immigration status are likely to be highly mobile in New Zealand as they try to avoid 'the Immigration', find continuing sources of work, and try not to wear out their family's welcome. ${ }^{14}$ Their situation is parallel to that of the woman who was the source case in the Auckland TB outbreak in 2002-3. The anxieties that accompany this lifestyle can inhibit access to health care and create stress levels that enhance the spread of infectious disease itself.

Although some Tuvalu migrants to New Zealand have had training in trades or professions, most find work as poorly paid labourers: cleaners, care-givers, process workers in factories and so on. Unemployment and underemployment are problems even for those with the right papers. Consequently, in Auckland where the majority of those who have come to New Zealand live (Statistics New Zealand, 2011), Tuvaluans typically live in crowded conditions, struggle with prejudice and cultural differences, participate in the informal economy, and eat a restricted and often marginally healthy diet. For some, access to education and health care is uncertain because of their residency status and their need to be highly mobile. Under these conditions of physical, social and psychological stress, latent infections, such as TB may develop into active disease, especially with high rates of diabetes in the community as well.

Tuvaluan communities in Auckland are grouped around churches and home island associations, with all islands being represented in the formal Tuvalu Community Association. Social and religious events dot the calendar, bringing different segments of the community together. In addition, there is much informal visiting and moving from household to household, especially by younger people and older folk related to several different households. The community's closeness and strong networks are very evident (Resture, Park \& Littleton, 2009).

CONSTRUCTING A WHAKAPAPA OF THE OUTBREAK

The 2003 TB outbreak in Auckland among Tuvaluans can therefore be seen as a product of a complex history. This involves the exploitative colonisation of Tuvalu itself and its insertion into global networks mainly as a supplier of 
labour for colonial enterprises which were too far away for either the colonial power or cooperative networks such as the South Pacific Board of Health and SPC to deliver effective health (or other) development. The lives of today's seasonal workers and mariners are highly mobile, and thus many Tuvaluans today inhabit an imagined transnational space that incorporates Tuvalu, New Zealand, Australia, and many other countries. The TB outbreak described for Auckland was located in this same historically produced, transnational realm and emerged through the relationships and processes we have described using a whakapapa model.

By working within the conceptual framework of an ecological and ancestral understanding of whakapapa, connections can be made between the ancient geological and biological events which formed the atolls and islands of Tuvalu, the historical and current social and biological interactions of factors such as filariasis, TB, obesity and diabetes; crowding, smoking and food and water insecurity; challenges from sea level rise and increasing storm surges caused by global climate change; local environment degradation and international politics. These phenomena can in turn be linked to transnational migration, global and regional labour markets, national immigration policies, and the distressing fact of a paediatric TB outbreak in 21st century Auckland. Together they constitute the transnational environmental realm of the 'Auckland' TB outbreak.

But what theoretical advantages does this model offer? What is the anthropological 'strangeness' that it can lay alongside and use to enhance or critique other social science models?

One advantage of the whakapapa model is its ability to integrate diverse elements from social science frameworks that have proven useful for understanding complexity: the interactions between diseases and noxious social conditions borrows from syndemics, historical political ecology contributes to understanding the role of colonialisms, while transnational theory provokes us to look beyond New Zealand to understand the Auckland outbreak, and also alerts us to transnational strategies of Tuvaluans and other agents. Thus, one role of whakapapa as social theory is to provide a mind map to integrate a range of approaches to complexity: to emphasise the multiple layers that need to be understood and the relations between them. But, we suggest that it has a unique further contribution to offer as well: namely, a framework for moral reasoning about the nature of these relations which is important to both social science and policy. 
In whakapapa narratives for kumara, misdeeds by the protagonists led to their being punished by having to contend with pests and weeds instead of being given useful (to humans) plants and animals. Heroes took risks, transgressed (but within certain limits) and might be punished. However, they might also save the day (or the kumara) if they acted correctly. The concept of utu and a rough and ready justice is never far away.

If we compare the narrative of the TB outbreak with the kumara narratives, we can see that something has gone wrong. The people, Tuvaluans (Banabans and Gilbertese too, but those are other stories) who were exploited in the first place and then neglected, end up getting the disease of TB and having this persist at frighteningly high rates for over 100 years. The beneficiaries of the exploitation, the political and economic colonisers, continue to benefit. Their/our current levels of resource consumption and greenhouse gas emission continue a privileged pattern of resource use and environmental destruction, with the result that Tuvaluans now face the looming possibility that their homeland will be destroyed by global climate change. ${ }^{15}$

For Paul Farmer, leading medical anthropologist and physician to the poor, liberation theology became a necessary underpinning for his work. He saw that the technical and analytical skills and theories provided by his academic and professional training were an essential starting place, though not themselves sufficient to guide its focus. A preferential option for the poor, shorthand for those who are suffering, provides the moral basis of Liberation Theology's philosophy. As he insisted, 'Making an option for the poor inevitably implies working for social justice' (Farmer, 2005:157). As a mode of analysing health systems, 'making an option for the poor' entails analysis which is historically deep and geographically broad (Farmer, 2005:158). We would argue, similarly, that whakapapa can provide an important platform for critical evaluation and guidance of our work as social scientists, as well as for evaluation of social policy in New Zealand and the wider Pacific region.

Gillett (2009:98) found inspiration in the concept of whakapapa in his discussion of: 'How exactly should we position indigenous knowledges in a discussion of policy in post-colonial society?' He notes that in ecosystem thinking, questions of normative morality are also more often asked than in 'normal science' (Gillett, 2009:99), where normative questions are usually dismissed as relevant only to ethics or the humanities. Ecosystem research raises questions about how we should act towards other entities with which we are intercon- 
nected. For example, how many paua (abalone), and of what size should we be permitted to take per day, during what season in order to preserve the species and be fair to others? Gillett proposes a convergence between Heidegger's metaphysics with its emphasis on care and entanglement, and the multi-layered approach to knowledge exemplified by whakapapa. He suggests that a 'genuine engagement' with 'indigenous knowledges' (Gillett, 2009: 111) leads to an understanding of our place in the order of things from which ethical guidelines for policy can flow.

In this particular narrative of a TB outbreak, we suggest that New Zealand, and the other countries involved, have been rather slow to grasp their place in the order of things and the implications of the transnational field which they, Tuvalu, and various other entities inhabit. New Zealand has clearly recognised certain needs of Tuvaluans 'over there' in Tuvalu, and has responded to them through aid programmes. It appears to have built a positive reputation in $\mathrm{Tu}$ valu as an aid and assistance donor. ${ }^{16}$ However, this good neighbourliness to Tuvalu and its residents is not matched by a similar focus on the needs of those Tuvaluans living transnational lives which include New Zealand (see also Bedford \& Bedford, 2010). The difficulties that contemporary Tuvaluans have with immigration in New Zealand, which force them underground and cause treatment delays, may well be as important in the Tuvaluan TB outbreak in New Zealand as more obvious ecological features such as household crowding, constrained access to work, discrimination and poor nutrition. As health workers found during the TB outbreak, and as has been repeatedly confirmed through more recent work (Hay, 2009; Miller, 2007; Ng Shiu, 2008), it is extremely difficult to do TB contact tracing, essential for stopping an outbreak, when people are fearful that any contact with someone official might result in deportation for themselves or someone close to them. The longer an infectious person goes without treatment, the greater the spread of disease and suffering. Discussion with community members during the Tuvalu TB Awareness Programme reinforced the major role that immigration fears play in peoples' responses to officialdom (Resture, Park \& Littleton, 2009).

As a better-off neighbour and beneficiary of economic colonialism in Tuvalu, with an 'advanced' economy which contributes more than our share to global climate change, New Zealand could use the whakapapa model to find ways to reciprocate for the benefits received and harms done. The principle of utu would support being more hospitable to people from this second smallest nation in the world (by population) who want - or seriously need - to include New Zealand as part of their transnational lives. In a whakapapa model, Tuvalu and New Zealand are part of the same environmental realm with mutual 
kinship obligations. Using whakapapa as social theory not only enables linkages among other theories dealing with social complexity, but supports our efforts to address moral dimensions in human affairs and social policy.

NOTES

1 The webpage link is http://www.arts.auckland.ac.nz/uoa/social-research-on-tband-health. The research on which this article is based was funded by the Health Research Council of New Zealand and a University of Auckland Faculty of Arts Research Development grant, for which we are very grateful.

2 We are indebted to Dr Mere Roberts for initial conversations which sparked the idea for this paper and to participants in the ASAANZ conference sessions, especially Dr Manuka Henare, for their suggestions and encouragement on a preliminary version of this paper. Special thanks to Dr Roberts and members of our research group for comments and corrections on more developed versions, and to the two anonymous reviews for SITES. A lively debate followed the presentation of this paper at a University of Auckland, Department of Anthropology seminar. One of the key discussion points was the propriety of using social theory derived from scholarship on Maori thought to discuss issues in the wider Pacific. No agreement was reached but several of the Maori and Pacific scholars in the room endorsed the attempt, while critiquing particulars. One person with both Maori and Tuvaluan ancestry characterised this kind of work as a koha: Maori thought along with Maori people derived from the wider Pacific therefore the work was part of a process of reciprocity. All errors are ours.

3 Despite whakapapa being widely used, it is likely to be understood in a variety of ways, some rather impoverished, in both English (Metge, 2005) and Maori (Roberts, et al., 2004).

4 We are indebted to conversations with Sagaa Malua, Tufoua Panapa as well as to Jackson's (2001) Tuvaluan Dictionary for the information on Tuvaluan terms and meanings. Project members are continuing to explore Tuvalu language and conceptual parallels and to further develop 'mind map' applications in our ongoing work. As both of our anonymous reviewers pointed out, Maori scholarship has led the way here.

5 In the 2001 Census the Tuvaluan population in New Zealand was recorded as 1965. It rose by $33 \%$ to 2628 in the 2006 Census (Statistics New Zealand, 2011). The Census planned for 2011 was postponed until 2013 because of the Christchurch earthquakes but the population appears to be growing. Within the Tu- 
valuan community these figures are thought to be a significant underestimation. The majority of Tuvaluans (estimated at around 80\%) live in Auckland but there are growing communities in other centres, most notably Wellington.

6 Cross country comparison of incidence rates is fraught with difficulty. Vigorous case finding will produce a higher 'incidence' rate. Similarly, differences in the way that population estimates are made may also produce differences in 'incidence' rates.

7 In any incidence rate for Tuvalu there is a large uncertainty range due especially to the difficulty of estimating the changing resident population, but the downward trend in TB rates seems robust, according to the long term figures provided by wно.

8 WPHC 91229108 F.10/18/4, Annual Report for 1946, Ellice Islands District. Western Pacific Archive, Auckland: The University of Auckland Library.

9 Rose, M. 1946. Medical and Sanitary Report for the Gilbert and Ellice Islands Colony. Wellington: Archives New Zealand, Agency H, Series 1, Box 496, Record 333/3 Alternate no 32602.

10 WPHC 91229108 F.10/18/4, Annual report for 1947, Ellice Islands District. Western Pacific Archive, Auckland: The University of Auckland Library; South Pacific Health Service, 1955 Inspector General's report 1951-1953. Wellington, Archives New Zealand, Agency H, Series 1, Box 496, Record 333/3 Alternate no 32602.

11 In the 19th and early 2oth centuries, deaths from what was clinically labelled consumption, phthisis and tuberculosis provide the basis for estimating rates. Workers came from other Pacific islands, China, including Hong Kong, Japan, and elsewhere. Tuberculosis has an ancient history in China and Japan. One questionably high TB mortality estimate based on a small study in China was 2230 per 100,000 in 1931 (Lei, 2010:257). Hong Kong had a lower rate, but one that was still alarmingly high, estimated by the local TB Association as 109 per 100,o0o for 1948 (http://www.antitb.org.hk/en/history.html). In Japan from the 19th century TB was recognised as a major contributor to mortality and was the leading infectious disease until about 1950 (Johnston, 1995).

12 In 1945 informal talks between officials of the WPHC and New Zealand canvassed future plans for Tuvalu. One was that Tuvalu might have a special relationship with New Zealand, like Tokelau. Another was that Tokelau and Tuvalu could both come under the aegis of the United Kingdom. However, nothing came of 
either (Macdonald, 2001:259).

13 Most years many fewer than 75 qualify (Sagaa Malua pers comm. 2011.)

14 This information derives from on-going and not-yet-published ethnographic research for the project being carried out by Sagaa Malua in Auckland.

15 For the Banabans, whose land is spread far and wide over global agriculture, this destruction of land was much more immediate and devastating (Teaiwa, 2005).

16 Three members of our research group, Dr Anne Chambers and Dr Keith Chambers and PhD student, Tufoua Panapa observed the local reactions to a Royal New Zealand Navy visit in 2010 which accomplished many important tasks and was very well received. During the recent severe and prolonged drought, our contacts in Tuvalu who were at the airport to greet the New Zealand team bringing extra desalination plants heard people around them murmuring their thanks to New Zealand.

\section{REFERENCES}

Anae, M., Mila-Schaaf, K., Coxon, El, Mara, D. and Sanga, T. 2010 Teu le Va-Relationships across Research and Policy in Pasifika Education: A Collective Approach to Knowledge Generation and Policy Development for Action towards Pasifika Education Success. Wellington: Ministry of Education.

Baer, H. and Singer, M. 2009 Global Warming and the Political Ecology of Health. Walnut Creek, California: Left Coast Press.

Bamford, S. 2007 Biology Unmoored: Melanesian Reflections on Life and Technology. Berkeley: University of California Press.

Bedford, C., Bedford, R. and Ho, E. 2010 'Engaging with New Zealand's Recognised Seasonal Employer work policy: The case of Tuvalu', Asian and Pacific Migration Journal, 19(3): 421-445.

Bedford, R. and Bedford, C. 2010 'International migration and climate change: A post-Copenhagen perspective on options for Kiribati and Tuvalu', in B.Burston (ed.) Climate Change and Migration: South Pacific Perspectives. Wellington: Institute of Policy Studies: 89-134. 
Central Intelligence Agency. 2011. Tuvalu. Retrieved from https://www.cia.gov/ library/publications/the-world-factbook/geos/tv.html

Chambers, K. and Chambers, A. 2001 Unity of Heart: Culture and Change in a Polynesian Atoll Society. Long Grove, Illinois: Waveland Press.

Curry International Tuberculosis Center. 2010 Draft Interim USAPI [United States Associated Pacific Islands] Standards for the Management of Tuberculosis and Diabetes. San Francisco: University of California. Retrieved from http:// www.nationaltbcenter.edu

Dunsford, D.A. 2008 Seeking the Prize of Eradication: A Social History of Tuberculosis in New Zealand from World War Two to the 1970s. Unpublished $\mathrm{PhD}$ thesis. Auckland: The University of Auckland.

Elias, D., Britton, S., Kassu, A. and Akuffo, H. 2007 'Chronic helminth infections may negatively influence immunity against tuberculosis and other diseases of public health importance', Expert Review of Anti-infective Therapy, 5(3): 475-484.

Farmer, P. 2005 Pathologies of Power: Health, Human Rights, and the New War on the Poor. Berkeley, California: University Press.

Foreign and Commonwealth Office, Overseas Development Administration, 1971 Living in the Gilbert and Ellice Islands Colony (revised edition). London: British Government.

Futter-Puati, D. 2010 Maki Maro: Tuberculosis in the Cook Islands: A Social History 1896-1975. Unpublished Master of Arts Thesis in History. Auckland: The University of Auckland.

Gani, A. 2009 'Some aspects of communicable and non-communicable diseases in Pacific Island countries', Social Indicators Research, 91(2):171-187.

Gillett, G. 2009 'Indigenous knowledges: circumspection, metaphysics, and scientific ontologies', SITES NS, 6(1):97-115.

Grimble, A. 1952 A Pattern of Islands. London: John Murray.

Grimble, A. 1957 Return to the Islands. London: John Murray. 
Hau'ofa, E. 1993 'Our sea of islands', in E. Waddell, V.Naidu, and E. Hau'ofa (eds) A New Oceania: Rediscovering Our Sea of Islands. Suva: University of the South Pacific Press: 2-18.

Hay, D. 2009 The experience of Having Tuberculosis (TB) Treatment in Auckland. Unpublished Dissertation for the Master of Public Health, Auckland: The University of Auckland.

Hountondji, P. J. 2002 'Knowledge appropriation in a post-colonial context', in C. A. Odora Hoppers (ed.) Indigenous Knowledge and the Integration of Knowledge Systems: towards a Philosophy of Articulation. Claremont, South Africa: New Africa Books: 23-38.

Huffer, E. and Qalo, R. 2004 'Have we been thinking upside-down? The contemporary emergence of Pacific theoretical thought', The Contemporary Pacific, 6(1):87-116.

Jackson, G.W. 2001 Tuvaluan dictionary. Suva: Oceania Printers.

Johnston, W. 1995 The Modern Epidemic: A History of Tuberculosis in Japan. Cambridge, Mass.: Harvard University Press.

Kawharu, M. 2010 In Search of Remedies and Reciprocity: Negotiating a Treaty Claim Settlement between Ngati Whatua o Kaipara and the Crown. Unpublished Master of Arts Thesis in Anthropology. Auckland: The University of Auckland.

Lei, S. 2010 'Habituating individuality: The framing of tuberculosis and its material solutions in Republican China, Bulletin of the History of Medicine, $84(2): 248-279$.

Lilomaiava-Doktor, S. 2009 'Beyond “migration”: Samoan population movement (malaga) and the geography of social space (vā)', The Contemporary Pacific, 21(1):1-32.

Littleton, J. and Park, J. 2009 'Tuberculosis and syndemics: Implications for Pacific health in New Zealand', Social Science and Medicine, 69:1674-1680.

Macdonald, B. 2001 [1982]. Cinderellas of the Empire: Towards a history of Kiribati and Tuvalu. Suva: Institute of Pacific Studies, University of the South Pacific. 
Mauss, M. 1969 [1950]. The Gift: Forms and Functions of Exchange in Archaic Societies. London: Cohen and West.

Metge, J. 2005 'Working in / playing with three languages', SITES, NS 2(2):83-90.

Mila-Schaaf, K. 2009 'Pacific health research guidelines: the cartography of an ethical relationship', International Social Sciences Journal, 6o(195):135-143.

Miles, J.A.R. 1997 Infectious Diseases: Colonising the Pacific? Dunedin: University of Otago Press.

Miller, J. 2007 The Perceptions and Beliefs of Healthcare Workers about Clients with Tuberculosis. Unpublished Dissertation for Masters of Public Health. Auckland: University of Auckland.

Ng Shiu, R., Park, J. and Kearns, R. 2008 'Placing the experience of Pacific peoples living with tuberculosis in Auckland, New Zealand, in J. Littleton, J. Park, A. Herring, and T. Farmer (eds) Multiplying and Dividing: Tuberculosis in Canada and Aotearoa New Zealand. Auckland: RAL-e 3:218-31.

Resture, S., Park, J. and Littleton, J. 2009 Evaluation of the Tuvalu Community TB Awareness Programme. Unpublished report to ARPHS and the Tuvalu Community. Auckland, Department of Anthropology, The University of Auckland.

Resture, S. 2010 Te Maama Pala: Continuity and Change in Coping with Tuberculosis in Tuvalu. Unpublished Master of Arts Thesis in History. Auckland: The University of Auckland.

Roberts, M., Haami, B., Benton, R., Satterfield, T., Finucane, M., Henare M. and Henare, M. 2004 'Whakapapa as a Maori mental construct: Some implications for the debate over genetic modification of organisms', The Contemporary Pacific, 16(1):1-28.

Roberts, M. 2010 'Mind maps of the Maori', GeoJournal, Dor:10.1007/s10708o10-9383-5.

Roberts, M. (in press) 'Revisiting the natural world of the Maori', in D. Keenan (ed.) Huia Maori History of Aotearoa New Zealand. Wellington: Huia Press. 
Schiller, N.G. 2007 'Transnationality', in D. Nugent and J Vincent (eds) A Companion to the Anthropology of Politics. Oxford: Blackwell: 448-468.

Sexton, K. Perera, S. and Pandey, S. 2008 Five Years of Molecular Typing of Mycobacterium Tuberculosis Isolates in New Zealand, 2003-7. A Report prepared for the Ministry of Health.

Singer, M. and Clair, S. 2003 'Syndemics and public health: Reconceptualising disease in bio-social context', Medical Anthropology Quarterly, 17 (4):423-441.

Statistics New Zealand. 2011 Census Home Page, 2006 Census, Pacific Peoples. Retrieved from http://www.stats.govt.nz

Strathern, M. 1987 'The limits of auto-anthropology', in A. Jackson (ed) Anthropology at Home. ASA Monograph 25. London and New York: Tavistock Press: $16-37$.

Teaiwa, K. M. 2005 'Our sea of phosphate: the disapora of Ocean Island', in G. Harvey and C.D. Thompson Jr (eds) Indigenous Diasporas and Dislocations. Aldershot: Ashgate Press:169-191.

Thaman, K. H. 2004 'Tauhi Vaha'a: A possible foundation for peace and intercultural understanding, Intercultural Education, Summer:32-36.

Vaioleti, T. M. 2006 'Talanoa research methodology: A developing position on Pacific research', Waikato Journal of Education, 12:21-34.

Viney, K., O'Connor, J. and Wiegandt, A. 2011 'The epidemiology of tuberculosis in Pacific islands countries and territories:2000-2007', Asia-Pacific Journal of Public Health, 23: 86-99.

Voss, L., Campbell, M., Tildesley, C., Hay, D., Vaughan, A. and Thornley, C. 2006 'Paediatric tuberculosis in a Pacific Islands community in New Zealand', Journal of Paediatrics and Child Health, 42:118-132.

Williams, M. 1971 Three Islands. Commemorating the Fiftieth Anniversary of the British Phosphate Commissioners, 1920 to 1970. Adelaide: The Griffin Press.

Williams, M. and Macdonald, B. 1985 The Phosphateers. A history of the British Phosphate Commissioners and the Christmas Island Phosphate Company. Carlton, Vic: Melbourne University Press. 
World Health Organisation. 2011a Tuvalu: Tuberculosis Profile [for 2009]. Retrieved from http://www.who/int/tn/data

World Health Organisation. 2011b Global Health Observatory Data Repository: Tuvalu. Retrieved from http://apps.who.int/ghodata 